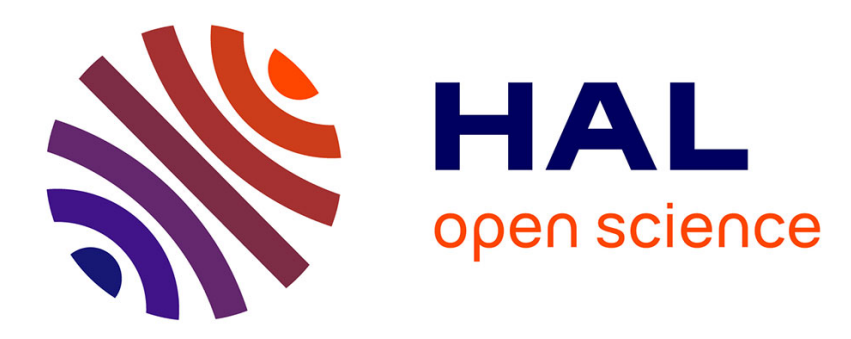

\title{
Relation between conformation and surface hydrophobicity of pea (Pisum sativum L.) globulins
}

\section{To cite this version:}

Relation between conformation and surface hydrophobicity of pea (Pisum sativum L.) globulins. Journal of Agricultural and Food Chemistry, 1989, 37 (5), pp.1236-1241. hal-02720129

\section{HAL Id: hal-02720129 \\ https://hal.inrae.fr/hal-02720129}

Submitted on 1 Jun 2020

HAL is a multi-disciplinary open access archive for the deposit and dissemination of scientific research documents, whether they are published or not. The documents may come from teaching and research institutions in France or abroad, or from public or private research centers.
L'archive ouverte pluridisciplinaire HAL, est destinée au dépôt et à la diffusion de documents scientifiques de niveau recherche, publiés ou non, émanant des établissements d'enseignement et de recherche français ou étrangers, des laboratoires publics ou privés. 


\section{Relation between Conformation and Surface Hydrophobicity of Pea (Pisum sativum L.) Globulins

\author{
J. Gueguen
}

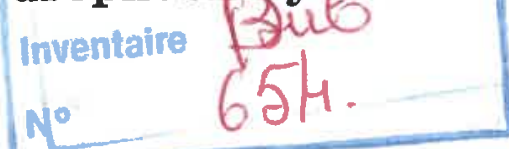

The surface hydrophobicity of pea globulins has been studied as a function of their conformational changes induced by $\mathrm{pH}$ variations. It was investigated by a hydrophobic ligand binding method by using 2-p-toluidinylnaphthalenesulfonate (TNS) as hydrophobic probe. In native form, the 11S- and 7S-like proteins (legumin, vicilin) exhibited a low surface hydrophobicity. Two classes of sites were found for legumin characterized by 8 and 11 sites of high and low TNS binding affinity constants, respectively. Vicilin exhibited one class of two or three sites. The dissociation and especially the unfolding of the polypeptide chains in both proteins, which occurred in acidic conditions, increased the number of TNS binding sites. Moreover, the profile of the Scatchard plot was modified, indicating a cooperative mode of ligand binding. This observation confirms that the hydrophobic B subunits of legumin are mainly buried in the native conformation.

Functional properties of proteins have been shown to be closely related to their surface hydrophobicity. The studies of Nakai (1983) and Nakai et al. (1986) and of $\mathrm{Li}$ Chan et al. (1984) on the structure-functionality relationship demonstrated that hydrophobicity is one of the more accurate characteristics of proteins defining their solubility and surface behaviors.

Legume seed proteins could be used as functional agents in food products. However, only a few studies were devoted to their surface hydrophobicity with exception for the $11 \mathrm{~S}$ and $7 \mathrm{~S}$ globulins of soybean in modified or native forms (Kato et al., 1984; Matsudomi et al., 1985; Kella et al., 1986). However, hydrophobicity of these proteins was not investigated with respect to the conformational changes easily induced by variations of $\mathrm{pH}$, ionic strength, or temperature.

In our previous studies on pea globulins (Pisum sativum L.), the efficiency of these proteins as surface-active agents was investigated (Dagorn-Scaviner et al., 1986, 1987). We have observed the higher ability of the $7 \mathrm{~S}$-like protein (vicilin) for decreasing the surface tension and its better emulsifying properties compared to the 11S-like protein (legumin). These results were discussed in light of the extensive work of Graham (1976) and Graham and Phillips (1976) and related to the conformation of these proteins, vicilin having a lower size and legumin being very rigid and close-packed. We have observed additionally that dissociation of legumin leads to the unfolding of the subunit polypeptides chains (Gueguen et al., 1988). Therefore, in order to improve the surface behavior of these globulins, a basic investigation of their accessible hydrophobicity was carried out as function of their conformational changes induced by $\mathrm{pH}$ or ionic strength modifications. It was studied by a hydrophobic ligand binding method. A special interest was devoted to the influence of dissociation on the surface hydrophobicity due to the unmasking of the hydrophobic subunits.

\section{MATERIALS AND METHODS}

Materials. Pea (variety Amino) globulins were purified by ion-exchange chromatography on DEAE-Sepharose (Pharmacia) and purified by gel filtration on ACA34 ultrogel (IBF Pharmindustrie) as described elsewhere (Gueguen et al., 1984).

Methods. The conformational modifications depending on $\mathrm{pH}$ and ionic strengths were obtained by solubilizing the two

Ministère de la Recherche et de l'Enseignement Supérieur, INRA, Laboratoire de Biochimie de Technologie des Proteines, Centre de Recherches Agroalimentaires, Rue de la Géraudière, 44026 Nantes Cedex 03, France. proteins in the following $0.1 \mathrm{M}$ buffer systems: citrate- $\mathrm{NaOH}$ buffers, $\mathrm{pH} \leq 3-4$; phosphate- $\mathrm{NaOH}$ buffers, $\mathrm{pH} 7$; glycine- $\mathrm{NaOH}$ buffers, $\mathrm{pH} \geq 9$.

Ultracentrifugation. Centrifugation was performed in linear isokinetic sucrose concentration gradients $(5-20 \%, w / v)$ established in the appropriate buffer. Protein solution $(0.25 \mathrm{~mL}$ at $5 \mathrm{mg} \mathrm{mL}-1$ ) were layered on the top of the tube and centrifuged for $18 \mathrm{~h}$ at $285000 \mathrm{~g}_{\mathrm{av}}$ and $20^{\circ} \mathrm{C}$, on a Beckman L565B centrifuge with a SW $40 \mathrm{Ti}$ rotor. Sedimentation coefficients were evaluated by the method of Martin and Ames (1961), as described by Gueguen et al. (1988).

Ligand Binding. Hydrophobicity was evaluated by the binding capacity of the protein for the apolar ligand $2-p$-toluidinylnaphthalenesulfonate (TNS) from Sigma Chemical Co. (McClure and Edelman, 1966). The rate of TNS binding to the protein was measured by ultrafiltration as suggested by Sophianopoulos et al. (1978) using the method developed by Popineau and Pineau (1987) for wheat proteins. A 0.5-mL portion of protein solution $\left((1-2) \times 10^{-5} \mathrm{M}\right)$ was added to $5 \mathrm{~mL}$ of $10^{-5}-3 \times 10^{-3} \mathrm{M}$ TNS solutions and the resultant mixture incubated for $20 \mathrm{~h}$ at $25^{\circ} \mathrm{C}$.

Each experiment was performed with at least 10 ligand to protein molar concentration ratios, which were generally in the range 1-300. The concentrations of TNS and proteins in the stock solutions were calculated on the basis of their molar absorbance solutions were calculated on determined assuming the value of (є). TNS concentration was determined assuming . For legumin and 18900 at $317 \mathrm{~nm}$ (Mclure ance coefficients at $278 \mathrm{~nm}$ were detervicilin the molar absorbance coefficients at $278 \mathrm{~nm}$ were determined to be 260 as molecular weights. The absorbance of protein and 160000 as molect from the turbidity. The final concentrations of TNS and protein in the protein-TNS mixture were calculated of TNS and protein in the protein-Th solutions and the dilution rate precisely determined by weighing the solutions added.

After incubation, the protein-ligand mixture was centrifuged After incubation, the prou YMT Amicon membranes (exclusion limit MW 25000) on an MPSI Amicon micropartition equipment. limit MW 25000 ) on an determined from the absorbance at $317 \mathrm{~nm}$ of the ultrafiltrate. It was verified that the cutoff of the membranes was low enough to avoid the loss of pea globulins.

The membranes were previously treated with $0.1 \mathrm{~N}$ natrium hydroxide and washed with the buffer by centrifugation. Then, in order to avoid the error due to nonspecific binding of TNS, each membrane and the equipment were washed twice by centrifugation of TNS solution at the same concentration as in the the rate of saturation by TNS for the equipment and membranes was controlled by the absorbance of the ultrafiltrate. Of the absorbance found for the initial TNS the ultrafiltrate. Of the absorbance found, indicating a satisfying saturation level for the membranes.

The binding isotherms ( $\bar{V}$ vs $\ln L_{\mathrm{f}}$ ) as well as the Scatchard plots $\left(\bar{V} / L_{\mathrm{f}}\right.$ vs $\left.\bar{V}\right)$ (Scatchard et al., 1957) were plotted. $\bar{V}$ is the plots $\left(V / L_{f}\right.$ TS number of TNS bound per mole of protein and $L_{f}$ the plotehard plots to the manism of ligand-protein in linear or not, is related to the mechanism of ligand-protein in teractions. Straight lines and convex or concave curves have been 


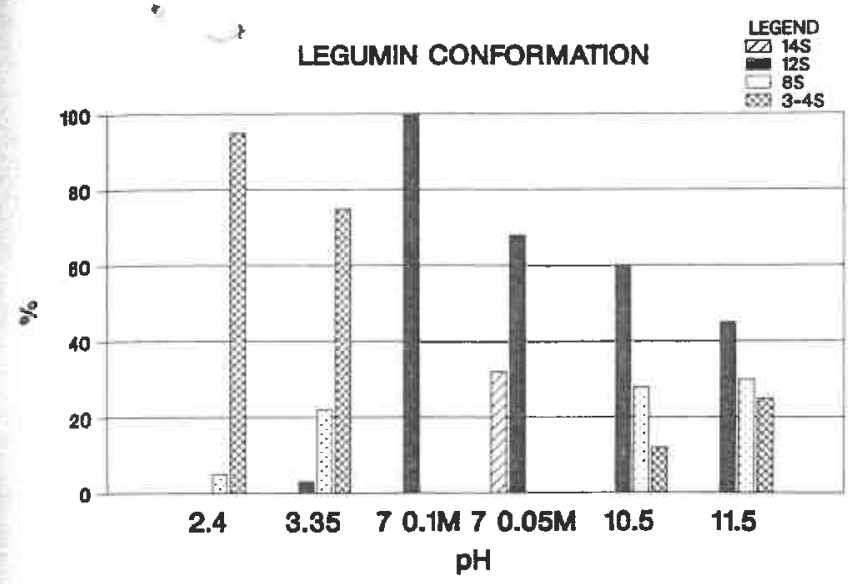

Figure 1. Influence of $\mathrm{pH}$ and ionic strength on legumin sedimentation coefficients.

described as being characteristic, respectively, of a single homogeneous class of noninteracting sites, of multiple classes of sites, and of at least a single class of sites with positive cooperativity (Thakur et al., 1980).

Moreover, this graphical analysis of the results provided the estimation of the binding parameters ( $n_{i}$, the number of sites in the $i$ th class; $k_{i}$, the corresponding affinity constant; $\beta$, the cooperativity parameter). The Scatchard plots were used for evaluating these parameters in the case of a single class of noninteracting sites and of a single class of sites with positive cooperativity. With $I_{0}$ and $I_{\max }$ the respective intercepts of the curve with the ordinate and abcissa axes and $S_{0}$ and $S_{\max }$ the corresponding slopes of the tangent to the curve in the respective intercept regions, the binding parameters have been calculated according to Thakur et al. (1980) as follows.

Single class of noninteracting sites:

$$
n=I_{\max } \quad k=-S_{0}
$$

Single class of sites with positive cooperativity:

$$
n=I_{\max } \quad k=I_{0} / I_{\max } \quad \beta=-S_{\max } / k
$$

For multiple classes of sites, the graphical representation of Klotz and Hunston (1971) (1/V vs $\left.1 / L_{f}\right)$ was preferentially employed because it seemed easier and more accurate for evaluating the binding parameters. Because two classes of sites were only found in the present study, the method described by Ray et al. (1966) could be used for the evaluation of $n_{1}, k_{1}$ and $n_{2}, k_{2}$.

\section{RESULTS}

Influence of $\mathbf{p H}$ on Conformation. The sedimentation coefficients of legumin were much more affected by $\mathrm{pH}$ variations than those of vicilin (Figures 1 and 2). Legumin sedimented only around $12.3 \mathrm{~S}$ in $\mathrm{pH} 7-9$ range, whereas vicilin adopted a native form $(8 \mathrm{~S})$ between $\mathrm{pH}$ 6 and 10. Both proteins dissociated mainly into 3-4-S sedimenting components under extreme pH conditions. At $\mathrm{pH} 11.5,45 \%$ of legumin and $20-25 \%$ of vicilin were still in their native conformation, considering the areas under the various sedimentation peaks.

Below pH 3.35, conformation of legumin is drastically affected. Intermediary oligomers sedimenting at $8.4 \mathrm{~S}, 5.9$ $\mathrm{S}$, and $3.7 \mathrm{~S}$ were observed. They were completely dissociated at $\mathrm{pH} 2.4$ and sedimented around $3.5 \mathrm{~S}$. The native form has completely disappeared and it was previously shown (Gueguen et al., 1988) that the low sedimenting polypeptides corresponded to the $\mathrm{AB}$ subunits, assuming an hexameric structure $6(\mathrm{AB})$ for the native legumin. On the other hand, the $8 \mathrm{~S}$ conformation of vicilin was still present at $\mathrm{pH} 2.4$ whereas $2.7 \mathrm{~S}$ sedimenting components were the major ones.

Apolar Ligand Binding. According to previous results, the apolar ligand binding was studied at the following $\mathrm{pHs}$ : $2.4,3.35,7,10.5,11.5$. Since these proteins tend to ag-

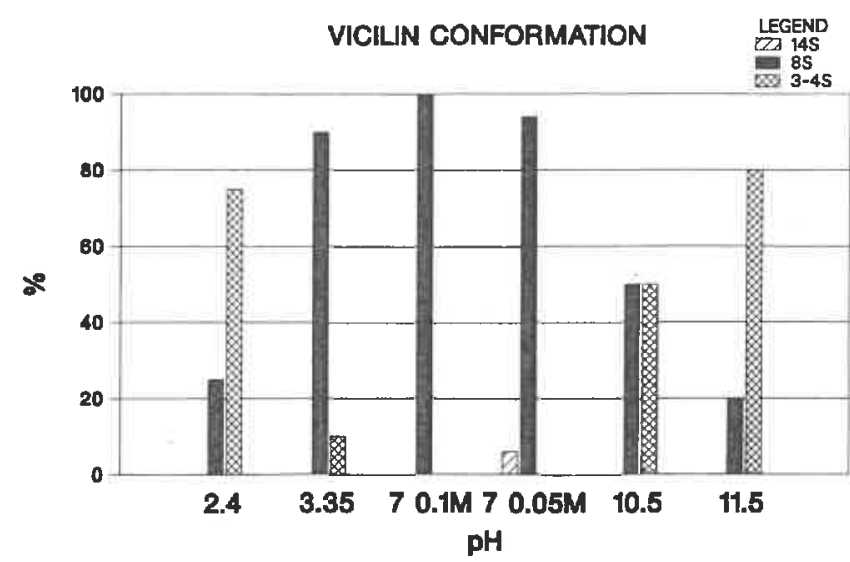

Figure 2. Influence of $\mathrm{pH}$ and ionic strength on vicilin sedimentation coefficients.

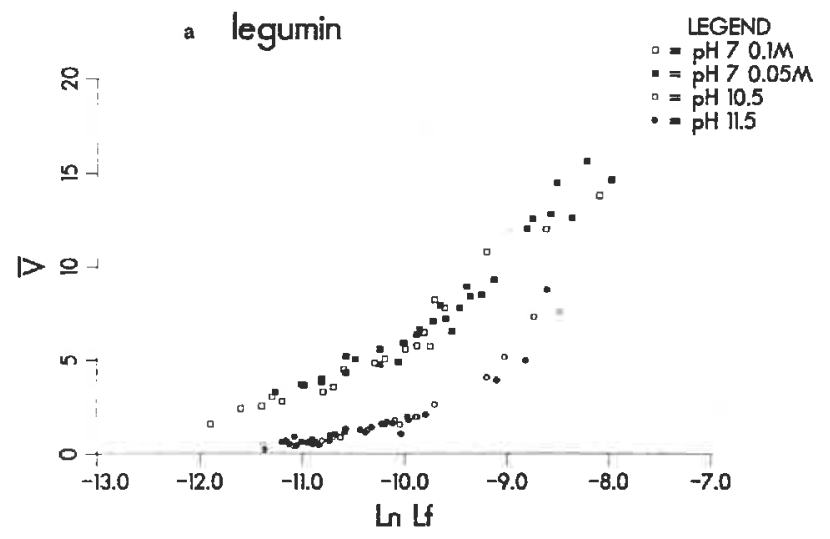

b legumin

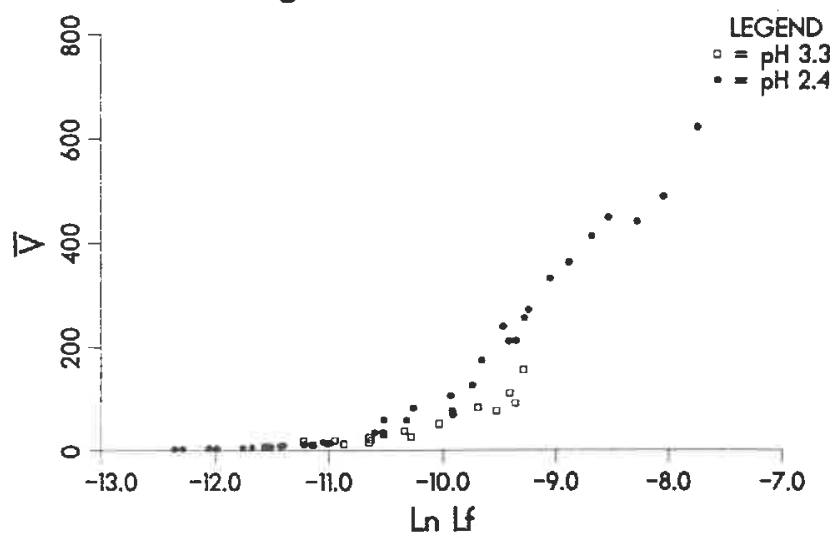

Figure 3. TNS binding isotherms of legumin: (a) neutral and alkaline $\mathrm{pH}$ range; (b) acidic $\mathrm{pH}$ range.

gregate at low ionic strengths, this study was also carried

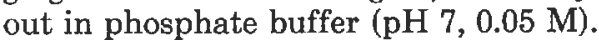

Legumin and Vicilin Isotherms. For the TNS concentration range investigated, both proteins exhibited continuous increase of $\bar{V}$ with the concentration of free ligand (Figures $3 \mathrm{a}, \mathrm{b}$ and $4 \mathrm{a}, \mathrm{b}$ ). In native form ( $\mathrm{pH} 7,0.1$ $\mathrm{M})$, legumin bound more ligand than vicilin. At $\mathrm{pH}$ 11.5, surface hydrophobicity of vicilin increased when compared with $\mathrm{pH} 7$, whereas surface hydrophobicity of legumin was lower as judged by TNS binding. Thus, the dissociation of legumin in alkaline $\mathrm{pH}$ range did not increase the protein binding capacity although the unmasking of the apolar residues of the inner part of the protein may have been expected. On the other hand, the amount of TNS bound to vicilin slightly increased with its degree of dissociation. This effect was mainly observed for the higher ligand concentrations. However, no significant differences 

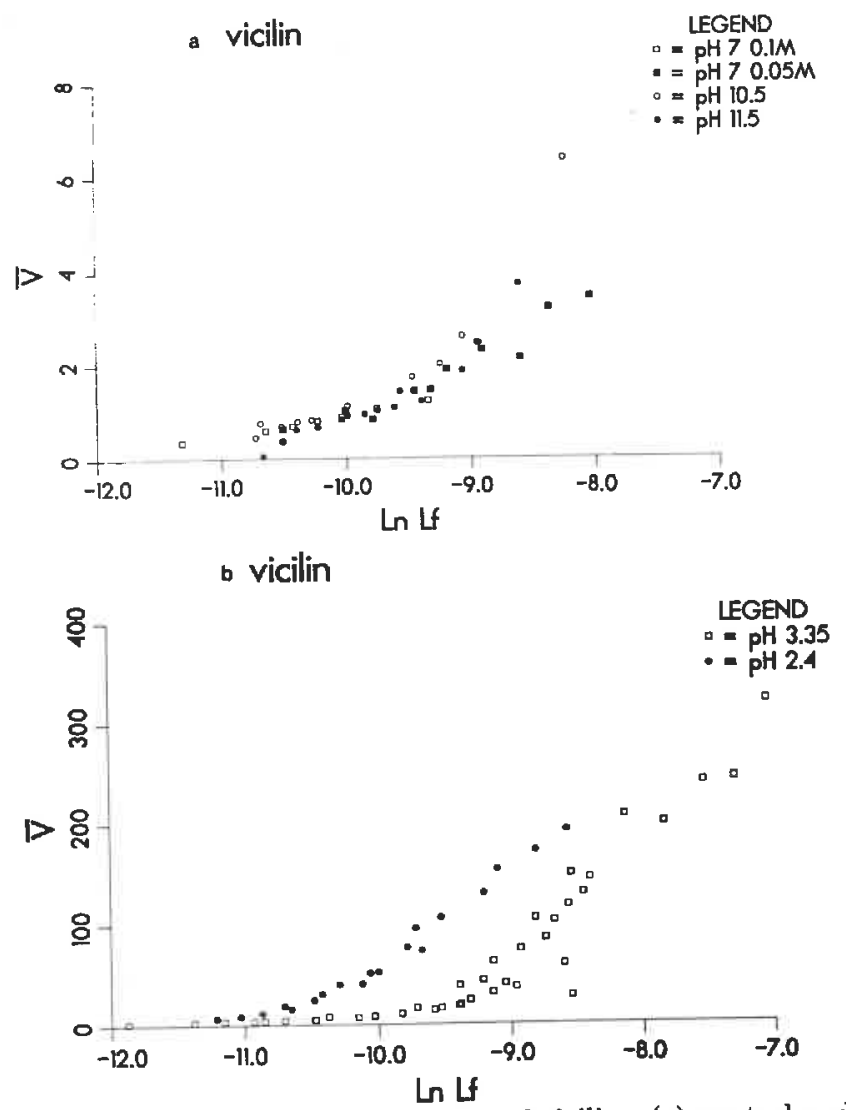

Figure 4. TNS binding isotherms of vicilin: (a) neutral and alkaline $\mathrm{pH}$ range; (b) acidic $\mathrm{pH}$ range.

in the protein binding capacity were noticed between $\mathrm{pH}$ 10.5 and 11.5 whereas dissociation is more effective at $\mathrm{pH}$ 11.5. It could indicate that the binding capacity of the protein is mainly ruled by the unfolding of its subunits than by the degree of dissociation.

Our results on the influence of the conformational changes on surface hydrophobicity of legumin agree well with those obtained by Kato et al. (1984) on the 11S soybean globulin. These authors have observed that the SDS binding capacity of this protein decreased above $\mathrm{pH}$ 6.0. It might signify that, even at $\mathrm{pH} 11.5$, the AB-dissociated subunits of legumin keep a close-packed conformation in which the hydrophobic regions of the B subunits are buried.

In acidic $\mathrm{pH}$, both pea globulins bind large amounts of hydrophobic ligand, indicating that their hydrophobic areas are exposed outward. This effect is very consistent with our previous results on legumin dissociation (Gueguen et al., 1988), which showed that complete unfolding of the dissociated subunits occurred in an acidic $\mathrm{pH}$ range, leading to exposure of all aromatic residues. Because the dissociation of vicilin led to similar oligomeric forms at $\mathrm{pHs}$ 2.4 and 11.5, the higher level of TNS binding for this globulin at $\mathrm{pH} 2.4$ compared to $\mathrm{pH} 11.5$ can only be explained by the unfolding of the polypeptide chains in acidic condition.

The large amount of TNS bound at the highest free ligand concentrations may also result from a cooperative procedure. The binding of new molecules of TNS is easier due to the binding of the former ones.

Number of Sites $(n)$ and Association Constant $(K)$. In order to interpret more precisely the mechanism of the TNS binding, we have plotted the results according to Scatchard et al. (1957) and Klotz and Hunston (1971).

Legumin. According to the Klotz or Scatchard plots (Figure 5a), native legumin ( $\mathrm{pH} 7,0.1 \mathrm{M}$ ) exhibited two
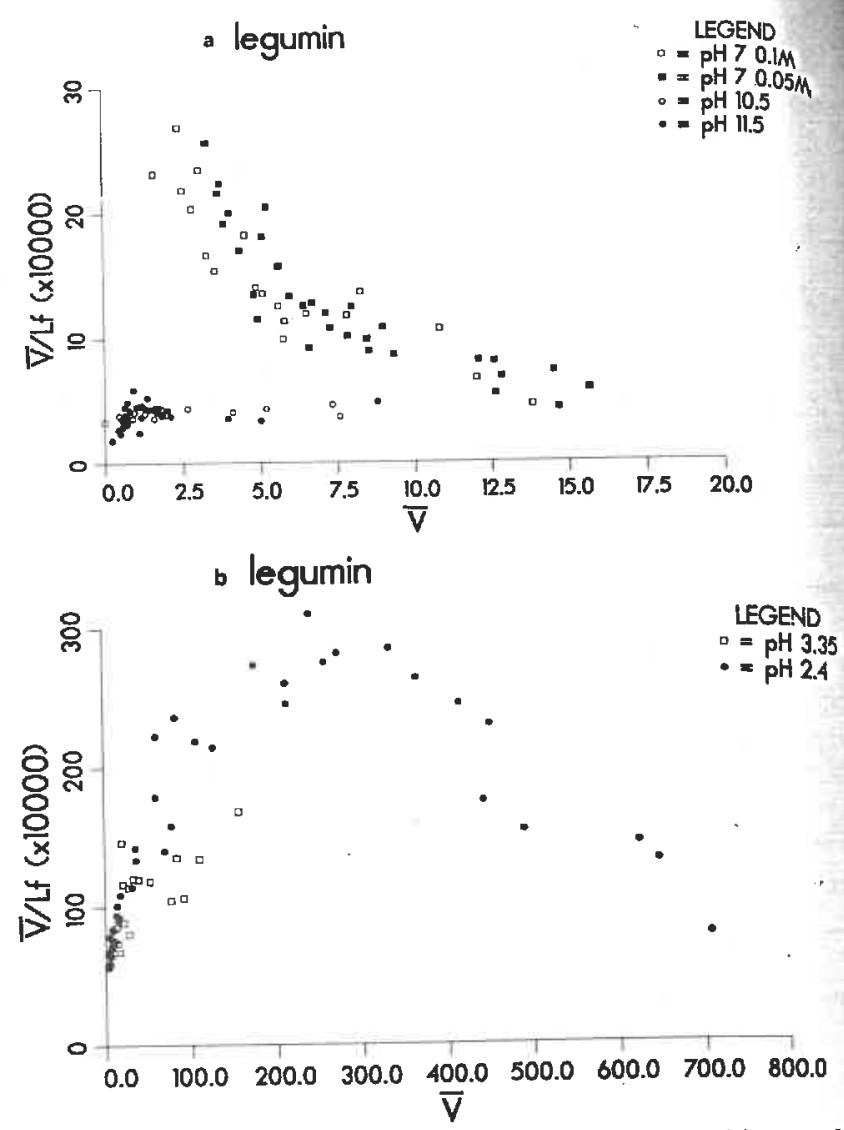

Figure 5. Scatchard plots of TNS binding by legumin: (a) neutral and alkaline $\mathrm{pH}$ range; (b) acidic $\mathrm{pH}$ range.

Table I. TNS Binding Parameters ${ }^{d}$ for Legumin and Vicilin

\begin{tabular}{|c|c|c|c|c|c|}
\hline \multirow[b]{2}{*}{$\mathrm{pH}$} & \multirow{2}{*}{$\begin{array}{c}\text { concn, } \\
\mathrm{M}\end{array}$} & \multicolumn{2}{|r|}{ legumin } & \multicolumn{2}{|r|}{ vicilin } \\
\hline & & $n$ & $k, \mathrm{M}^{-1}$ & $n$ & $k, \mathbf{M}^{-1}$ \\
\hline 7 & 0.1 & $\begin{array}{l}n_{1}^{a}=8^{*} \\
n_{2}^{b}=11^{*}\end{array}$ & $\begin{array}{l}k_{1}=4.5 \times 10^{4 *} \\
k_{2}=3.5 \times 10^{3 *}\end{array}$ & $2-3$ & $1.7 \times 10^{4}$ \\
\hline & 0.05 & $\begin{array}{l}n_{1}=8^{*} \\
n_{2}=15^{*}\end{array}$ & $\begin{array}{l}k_{1}=5.2 \times 10^{4 *} \\
k_{2}=2.7 \times 10^{3 *}\end{array}$ & 6 & $4.0 \times 10^{3}$ \\
\hline 11.5 & & $16-18$ & $3.9 \times 10^{2}\left(\beta^{c} 7.7\right)$ & & \\
\hline $\begin{array}{l}3.35 \\
2.4\end{array}$ & & $\begin{array}{l}464 \\
895\end{array}$ & $\begin{array}{l}4.0 \times 10^{2}(\beta 5.4) \\
5.7 \times 10^{2}(\beta 8.2)\end{array}$ & 244 & $1.5 \times 10^{3}(\beta 7$ \\
\hline & & & & & \\
\hline
\end{tabular}

a Number of sites of strong affinity. ${ }^{b}$ Number of sites of weak af Number of sites of strong aftinity. $d$ These binding parameters wer finity. 'Constant of cooperativity. were determined from Klotz plots.

classes of sites (Table I). Aggregation at lower ionic strength ( $\mathrm{pH} 7,0.05 \mathrm{M}$ ) did not affect these binding parameters very much. The strong binding class of sites is characterized for both ionic strengths by an equivalent number of sites having close binding constants (around 5 number of sites having close binding constants (around slightly increased when the ionic strength decreased. The profile of the Scatchard plot was considerably modified in the alkaline $\mathrm{pH}$ (Figure $5 \mathrm{a}$ ). The ratio $\bar{V} / L_{\mathrm{f}}$, which increased with $\bar{V}$ for the lower concentration of TNS, reached a with for the low ten terease. That was de scribed as resulting from a cooperative mode of binding by Thakur et al. (1980). In the present study, however, when TNS concentration reached higher values, the $\bar{V} / L_{f}$ ratio remained at a constant value or even increased instead of decreasing. The protein seemed to bind continuously new TNS molecules, and its binding ability was never saturated. It seems that for the higher TNS concentrations conformational modifications are induced by the binding of the hydrophobic probe and lead to appearance of new accessible hydrophobic sites. This phe- 
nomenon is more significant at $\mathrm{pH} 10.5$ than at $\mathrm{pH} 11.5$. Due to this plateau for $\bar{V} / L_{\mathrm{f}}$, the determination of binding parameters was impossible at $\mathrm{pH} 10.5$. On the other hand, they could be calculated at $\mathrm{pH} 11.5$ for the experimental data corresponding to $\bar{V}$ values lower than 6 . The number of cooperative binding sites was found to be around 16-18, which is close to the total number of sites obtained at $\mathrm{pH}$ 7. They are, however, characterized by an affinity constant intermediate between those obtained for the weak and the strong binding sites existing in the neutral conditions. The cooperativity parameter was found around 7.7. Assuming that the last part of the Scatchard plot, corresponding to the plateau region, could be related to modifications of the protein conformation due to ligand binding, the number of sites was also calculated by taking into account the $\bar{V}$ values lower than 2.5 only. It led to eight sites at $\mathrm{pH}$ 10.5-11.5 as for neutral $\mathrm{pH}$. In conclusion, the partial dissociation occurring in the alkaline $\mathrm{pH}$ range did not increase the number of sites, but a high concentration of TNS seemed to be able to open the protein packed structure, probably by modifying the hydrophobic interactions that stabilize the oligomeric structure.

In acidic conditions the binding of TNS by legumin is also cooperative, as shown by the profile of the Scatchard plots (Figure 5b). At pH 3.35, however, the Scatchard plot is changed because $V / L_{f}$ ratios increased instead of decreasing for the $\bar{V}$ values higher than 90 . For this reason, experimental data were only obtained for the lower $\vec{V}$ values. The high values of $\bar{V} / L_{\mathrm{f}}$ in the last part of the curve should be explained by secondary modifications of the protein conformation induced by the hydrophobic probe. Intermediate sedimenting components are still existing at $\mathrm{pH} 3.35$ and could dissociate and unfold if the free ligand concentration is high enough, TNS acting as

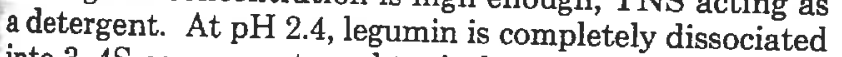
into 3-4S components and typical cooperative Scatchard profile could be obtained.

Taking into account these experimental data, the binding parameters were evaluated only at $\mathrm{pH} 2.4$. The number of cooperative sites is unexpectedly large (Table I) and corresponds to about one site for three to four amino acids. It is calculated on the basis of 2976 as total number of amino acids, according to the sequence data of Lycett et al. (1984) and assuming identical amino acid composition for the various subunits of legumin. It is known that this last hypothesis is not true and led consequently to an approximate value; it was however kept because it allowed an estimate for the order of magnitude for the binding ability of the protein. The binding constant is close to that obtained in basic conditions and indicates a relatively low affinity for the ligand. The cooperativity parameter (8.2) is also close to the previous one at $\mathrm{pH}$ 11.5. The complete infolding of the polypeptide chain at $\mathrm{pH} 2.4$ should explain the high accessibility of the inner hydrophobic part of the protein and the very high number of TNS binding
sites.

Vicilin. Only one class of binding sites (Figure 6a) was detected in the case of vicilin at $\mathrm{pH} 7$ whatever the ionic strength of the buffer, 0.1 or $0.05 \mathrm{M}$. On the other hand, the binding parameters are changed; the number of sites, Which is only two or three at $0.1 \mathrm{M}$, increased to six at 0.05 $M$, but the binding constant decreased. As for legumin, aggregation tends to induce a higher surface hydropho-
sicity.

In alkaline $\mathrm{pH}$ some cooperativity occurred as shown by the Scatchard plots (Figure 6b). However, the ratio $\bar{V} / L_{\text {f }}$ remained constant for the higher TNS concentrations, and t. Was not possible to determine precisely the number of a vicilin
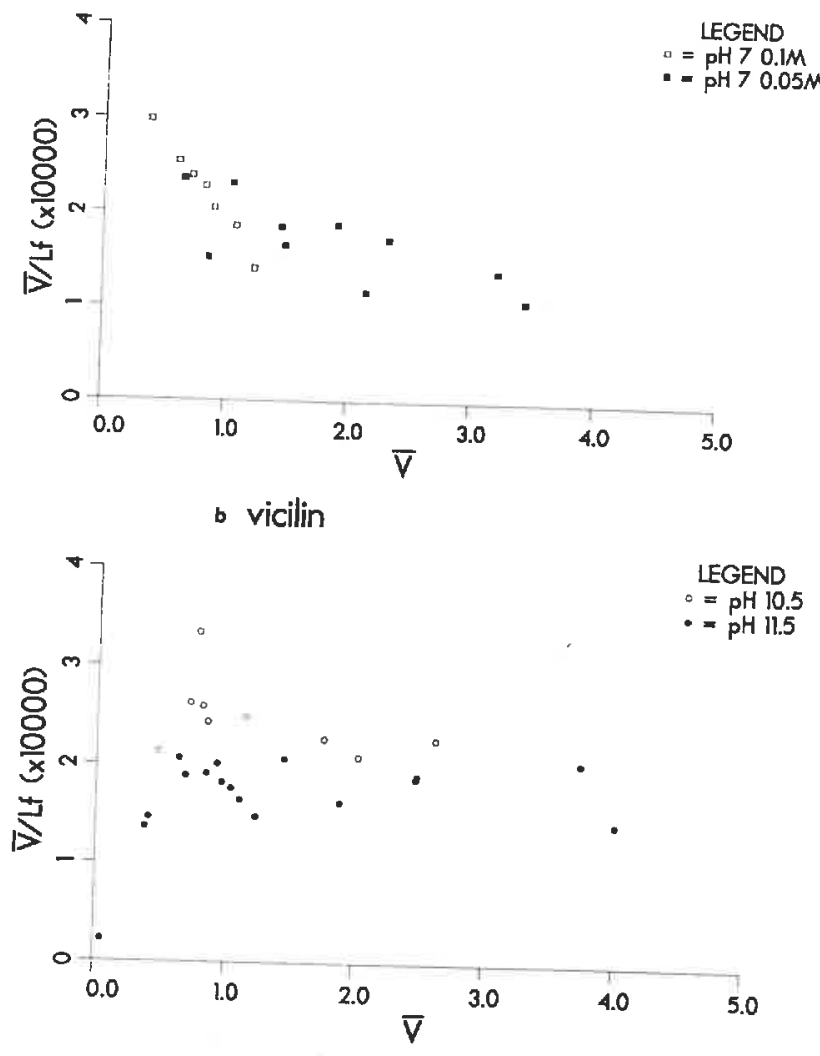

c vicilin

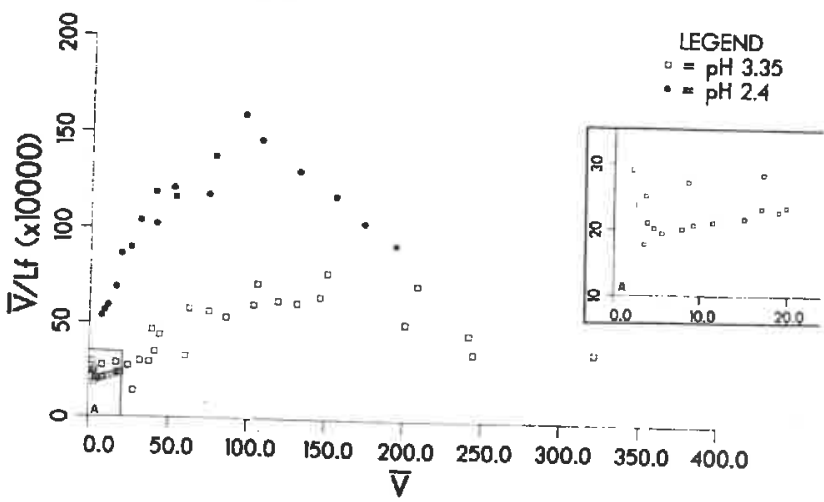

Figure 6. Scatchard plots of TNS binding by vicilin: (a) neutral $\mathrm{pH}$ range; (b) alkaline $\mathrm{pH}$ range; (c) acidic $\mathrm{pH}$ range; $\left(\mathrm{c}_{\mathrm{A}}\right)$ detail of the first part of the curve obtained for $\mathrm{pH} 3.35$.

sites. However, if we only considered the regular part of the Scatchard plot $(\bar{V}<1.2)$, as previously done for legu$\mathrm{min}$, three sites were found at $\mathrm{pH} 11.5$. This value is very close to the corresponding one obtained in neutral conditions.

In acidic conditions, TNS binding is ruled by a cooperative procedure (Figure 6c). At $\mathrm{pH} 2.4$, vicilin exhibited as legumin a very high number of cooperative sites, which are exposed by the dissociation and the unfolding of the protein. It corresponds to about $1 \mathrm{~mol}$ of TNS bound $/ 5$ amino acid residues, assuming around 1230 amino acids for vicilin, on the basis of the sequence data of Lycett et al. (1983). This value is indeed approximate because of the same reasons as previously explained for legumin. The cooperativity parameter (7.7) is very close to that obtained previously for legumin. At pH 3.35, the number of coop-

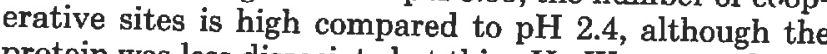
protein was less dissociated at this $\mathrm{pH}$. We are unable to interpret this observation. At this $\mathrm{pH}$, however, the Scatchard plots could be divided into two parts, the first 
one corresponding to the linear part observed for the $\bar{V}$ values lower than 10 (Figure $6 c_{A}$ ). Considering this part only, around six sites were graphically detected as for vicilin at $\mathrm{pH} 7,0.05 \mathrm{M}$. The mechanism of binding could be compared to that previously described for legumin at $\mathrm{pH}$ 10.5-11.5, high TNS concentrations inducing a higher accessibility of the hydrophobic areas of the protein.

\section{DISCUSSION}

The two pea globulins exhibit as native proteins relatively low surface hydrophobicity. On the basis of their molecular weights, the number of binding sites are low compared to wheat gliadins ( $n \approx 11-40$ ), according to the data of Popineau and Pineau (1987). However, the comparison of their respective hydrophobic amino acid profiles cannot explain such a difference. The repetitive domain of gliadin is indeed relatively hydrophilic; on the other hand, the B subunits of legumin are more hydrophobic. Thus, the lower surface hydrophobicity of the 7S- and 11S-type proteins compared to wheat prolamins was explained by their closely packed structure compared to the unfolded polypeptide chains for the gliadins, in the experimental conditions used by the authors. It indicates especially that only a few hydrophobic sites of the B subunits of legumin are accessible and probably buried in the inner part of the protein when the legumin is under its native conformation.

For legumin, the existence of eight strong sites of TNS binding does not correlate well with the molecular hexameric model proposed by Badley et al. (1975) or the trigonal antiprism model of Plietz et al. (1987). Assuming one or two sites for each AB subunit, 6 or 12 sites should have been found. In opposite, it agrees with the previous results of Miles et al. (1985), which showed that none of the models was in complete agreement with the experimental sedimentation, translational diffusion, and small-angle X-ray data. These authors conclude that "the modeling is restricted by the assumption that the subunits are identical and spherical". It is assumed here that some of the AB subunits could bind more (or less) TNS than the others leading to 8 sites instead of 6 (or 12). It proved that the six $A B$ subunits have various accessible hydrophobicity.

In the case of vicilin, the number of sites is related to the trimeric structure of this protein but was not found to be exactly three. The experimental value between two and three indicated that some subunits are characterized by lower accessibility of their hydrophobicity. As previously noticed for legumin, aggregation led to new hydrophobic areas.

For both proteins, dissociation induces cooperativity of the TNS binding, but the mode of binding depends on the degree of dissociation. When intermediary sedimenting oligomers are still present, the Scatchard plots can be divided into two different parts corresponding to the low and high concentrations of free ligand. At low concentrations, the curve adopted the regular profile, increasing and then decreasing. On the other hand, for the highest TNS concentration, $\bar{V} / L_{\mathrm{f}}$ remained at a constant value or tended to increase. That was observed for both proteins in alkaline $\mathrm{pH}$ range and at $\mathrm{pH} 3.35$. Besides, if the number of sites is calculated taking into account this first part of the curve only, the values found were very close to those obtained for the native proteins (eight for legumin at $\mathrm{pH} 10.5-11.5$, three and six for vicilin at $\mathrm{pH} 11.5$ and 3.35). Thus, when these globulins are partly dissociated, the surface hydrophobicity increased only when the hydrophobic probe concentration reached the higher values; the ligand binding seems to shift the equilibrium reaction protein $\leftrightarrow$ dissociated components toward dissociation. That should make the binding of new TNS molecules easier and explains the cooperative mode of binding and the profile of the Scatchard plot.

When the globulins are completely dissociated at $\mathrm{pH} 2.4$ the number of sites reached unexpected high values. This might signify that ionic binding instead of hydrophobic interactions could be involved in the ligand binding. However, this possibility is insignificant according to McClure et al. (1966). These authors showed in their basic study of this hydrophobic probe that ionic binding can be neglected compared to hydrophobic interactions even at extreme $\mathrm{pH}$. It is confirmed by the number of sites found for vicilin at $\mathrm{pH} 3.35$ for the lower TNS concentrations, which was close to those obtained at $\mathrm{pH} 7$. Thus, the very high degree of TNS binding at $\mathrm{pH} 2.4$ can be related to the unfolding of the polypeptide chains and to the complete accessibility of the hydrophobic amino acids. Gliadins, which were studied by Popineau and Pineau (1987) as unfolded polypeptides, bind about 1 molecule of TNS per 19 amino acid residues. The comparison of the distribution of the hydrophobic amino acid residues through the sequence of the A and B subunits of legumin with gliadins showed that the hydrophobicity is distributed all over the sequence of legumin polypeptides whereas the hydrophobic residues were mainly present in the nonrepetitive domain of gliadins. Consequently, the number of amino acid residues per molecule of bound TNS was compared to that obtained for the nonrepetitive domain of gliadins assuming that the number of TNS bound by this domain is proportional to its content in hydrophobic amino acid residues. The nonrepetitive domain of $\gamma$ gliadin contains 162 residues: 53 hydrophobic ones compared to the 308 residues of the whole protein and its 76 hydrophobic ones (Sugiyama et al., 1986). It leads to 13 sites for this domain and a ratio of amino acid residues per bound TNS of 12. The corresponding ratios, evaluated for legumin and vicilin around 3 and 5 respectively, are of the same order of magnitude but significantly lower. This can be related to a high experimental value for the number of sites due to the binding of ligand to previously bound molecules. It can be easily imagined that the TNS molecules are bound to the unfolded protein close to each other and consequently may induce the formation of new hydrophobic areas and stimulate the binding of other molecules of TNS to the former ones. This could lead to successive layers of TNS molecules stacked by electron $\pi$ interactions between their aromatic cycles. For this reason, the number of sites is probably overestimated at $\mathrm{pH} 2.4$; in spite of this overestimation, we think however that the surface hydrophobicity of the two pea globulins is considerably increased in acidic conditions when the proteins are completely unfolded.

The increase of surface hydrophobicity by dissociation and unfolding of the globular proteins has to be managed for improving their emulsifying and foaming properties. The highly hydrophobic unfolded polypeptides should be The ficient to adsorb at apolar phase/water interface and results of some authors (Schwenke et al., 1983) on the influence of $\mathrm{pH}$ treatments on the emulsifying behavior of faba bean isolates. This observation has however to be confirmed by the study of the purified proteins, and we are planning to study the influence of the conformational modifications on the emulsifying properties of these two pea globulins.

\section{ACKNOWLEDGMENT}

Thanks are due to J. Barbot for his technical assistance 
nd T. Hacrtle and Y. Popineau for their helpful comments on the manuscript.

\section{IITERATURE CITED}

Badley, R. A.; Atkinson, D.; Hauser, H.; Oldani, D.; Green, J. P. Stubbs, J. M. The structure, physical and chemical properties of the soy bean protein glycinin. Biochim. Biophys. Acta 1975 412,214

Dagorn-Scaviner, C.; Gueguen, J.; Lefebvre, J. A comparison of interfacial behaviours of pea (Pisum sativum L.) legumin and vicilin at air/water interface. Die Nahrung 1986, 3-4,337.

Dagorn-Scaviner, C.; Gueguen, J.; Lefebvre, J. Emulsifying properties of pea globulins as related to their adsorption behaviors. J. Food Sci. 1987, 52, 335 .

Graham, D. E. Structure of adsorbed protein films and stability of foams and emulsions. Ph.D. Thesis, CNAA, London.

Graham, D. E.; Phillips, M. C. The conformation of proteins at interfaces and their role in stabilizing emulsions. In Theory and Practice of Emulsion Technology; Smith, A. L., Ed.; 1976; p 75 .

Gueguen, J.; Vu, A. T.; Schaeffer, F. Large scale purification and characterization of pea globulins. J. Sci. Food Agric. 1984, 35, 1024.

Gueguen, J.; Chevalier, M.; Barbot, J.; Schaeffer, F. Dissociation and aggregation of pea legumin induced by $\mathrm{pH}$ and ionic strength. J. Sci. Food Agric. 1988, 44, 167.

Kato, A.; Matsuda, T.; Matsudomi, N.; Kobayashi, K. Determination of protein hydrophobicity using a SDS binding method. J. Agric. Food Chem. 1987, 32, 284.

Kella, N. K. D.; Barbeau, W. E.; Kinsella, J. E. Effect of oxidative sulfitolysis of disulfide bonds of glycinin on solubility, surface hydrophobicity and in vitro digestibility. J. Agric. Food Chem. 1986, 34, 251.

Klotz, I. M.; Hunston, D. L. Properties of graphical representations of multiple classes of binding site. Biochemistry 1971, 10,3065.

Li Chan, E.; Nakai, S.; Wood, D. F. Hydrophobicity and solubility of meat proteins and their relationship to emulsifying properties. J. Food Sci. 1984, 49, 345.

Lycett, W. G.; Delauney, A. J.; Gatehouse, J. A.; Gilroy, J.; Croy, R. R. D.; Boulter, D. The vicilin gene family of pea (Pisum sativum L.): a complete CDNA coding sequence for previcilin. Nucleic Acids Res. 1983, 11, 2367.

Lycett, W. G.; Croy, R. R. D.; Shirsat, A. H.; Boulter, D. The complete nucleotide sequence of a legumin gene from pea (Pisum sativum L.). Nucleic Acids Res. 1984, 12, 4493.

Martin, R. G.; Ames, B. N. A method for determining the sedi- mentation behavior of enzymes. Application to protein mixtures. J. Biol. Chem. 1961, 236. 1372.

Matsudomi, N.; Mori, H.; Kato, A.; Kobayashi, K. Emuslifying and foaming properties of heat denatured soybean $11 S$ globulins in relation to their surface hydrophobicity. Agric. Biol. Chem. $1985,49,915$.

McClure, W. O.; Edelman, G. M. Fluorescent probes for conformational states of proteins. I - Mechanism of fluorescence of 2-p-Toluidinylnaphthalene-6-sulfonate, a hydrophobic probe. Biochemistry 1966, 5, 1908

Miles, J. M.; Morris, V. J.; Wright, D. J.; Bacon, J. R. A study of the quaternary structure of glycinin. Biochim. Biophys. Acta $1985,827,119$.

Nakai, S. Structure - function relationships of food proteins with emphasis on the importance of protein hydrophobicity. $J$. Agric. Food Chem. 1983, 31, 676.

Nakai, S.; Li Chan, E.; Hayakawa, S. Contribution of protein hydrophobicity to its functionality. Die Nahrung 1986, 30, 327.

Plietz, P.; Drescher, B.; Damaschun, G. Relationship between the amino acid sequence and the domain structure of the subunits of the 11S seed globulins. Int. J. Biol. Macromol. 1987, 9,161.

Popineau, Y.; Pineau, F. Investigation of surface hydrophobicities of purified gliadins by hydrophobic interaction chromatography, reversed phase high performance liquid chromatography and apolar ligand binding. J. Cereal Sci. 1987, 5, 215.

Ray, A.; Reynolds, J. A.; Polet, H.; Steinhardt, J. Binding of large organic anions and neutral molecules by native bovine albumin. Biochemistry 1966, 5, 2606.

Scatchard, G.; Coleman, J. S.; Shen, A. L. Physical chemistry of protein solutions. VII - The binding of some small anions to serum albumin. J. Am. Chem. Soc. 1957, 79, 12.

Schwenke, K. D.; Rauschal, E. J.; Robowsky, K. D. Functional properties of plant proteins. Part 4. Foaming properties of modified proteins from faba beans. Die Nahrung 1983, 27, 335 .

Sophianopoulos, J. A.; Durham, S. J.; Sophianopoulos, A. J. Ragsdale, H. L.; Cropper, W. P. Ultrafiltration is theoretically equivalent to equilibrium dialysis but much simpler to carry out. Arch. Biochem. Biophys. 1978, 187, 132.

Sugiyama, T.; Rafalski, A.; Söll, D. The nuceotide sequence of a wheat gamma gliadin genomic clone. Plant Sci. 1986, 44, 205.

Thakur, A. K.; Jaffe, M. L.; Rodbard, D. Graphical analysis of ligand binding systems: evaluation of Monte Carlo studies. Anal. Biochem. 1980, 107, 279.

Received for review August 24, 1988. Accepted March 14, 1989. 